\title{
THE ROLE OF DESALINATION IN WATER MANAGEMENT IN SOUTHEAST SPAIN
}

J.C. Hernández-Sánchez (1), N. Boluda-Botella (2) and J.L. Sánchez-Lizaso (3)

(1) Institute of Water and Environmental Sciences, University of Alicante. P.O. Box 99, 03080 Alicante, Spain.

(2) Chemical Engineering Department, University of Alicante. P.O. Box 99, 03080 Alicante, Spain.

(3) Department of Marine Sciences, University of Alicante. P.O. Box 99, 03080 Alicante, Spain.

Tel. +34 965903534; Fax +34 965909897; email: jcarlos.hersa@gmail.com; nuria.boluda@ua.es; JL.Sanchez@ua.es;

\begin{abstract}
The aim of this paper is to evaluate the importance of seawater desalination to the supply of fresh water to SE Spain, in order to tackle the problem of the shortage of water resources.

The Mancomunidad de los Canales del Taibilla (MCT) supplies water to a population of more than 2,400,000 inhabitants in SE Spain. Resources managed by the MCT include the Taibilla river basin, water from the Tajo-Segura transfer, other unusual occasional groundwater contributions and from 2003, sea water desalination. Four desalination plants: Alicante I and II and San Pedro del Pinatar I and II together with resources from other desalination plants provide a significant amount of resources. For a decade (20042013 ) the resources coming from sea water desalination averaged $20.2 \%$ of all the resources used by MCT, with $432 \mathrm{Mm}^{3}$ of total production in the period studied. However, the yearly contribution of desalination has changed depending on the availability of other resources.

Moreover, seawater desalination has been essential to ensure water supply in the Alicante and Murcia areas. This resource has been important in periods of shortage, but also in unusual exploitation situations, such as that of the post-transfer tunnel detachment, which was classified as the most important breakdown of this infrastructure within its long lifetime. Moreover, scenarios of future climate changes could increase demands for water supply.
\end{abstract}

\section{Keywords}

Water resource diversification, desalination, Mancomunidad de los Canales del Taibilla, water supply, Mediterranean Region

\section{Introduction}

The Southeast of Spain presents a structural problem; inadequate water resources in quantity and quality to satisfy the demands of drinking water. The recurrent and frequent drought periods (1980-1982, 1993-1995, and 2005-2008) have generated important 
crises and greatly complicated water management [1]. The Mancomunidad de los Canales del Taibilla (MCT) currently supplies water to official establishments, organisations and 80 municipalities spread over the regions of Murcia, Valencia and Castilla La Mancha (Figure 1). In this area, the population supplied corresponds to more than 2,400,000 inhabitants, which increases to more than 3 million in the summer period due to tourism. To deal with this demand for water, the MCT has had to evolve throughout its long history. The insufficiency of existing resources for the progressive increase of the population in this area has motivated the continuous search for new water resources by the MCT agency: initially (1927) with the Taibilla river resources, since 1978 with the contribution from the Tajo-Segura transfer that is a $286 \mathrm{~km}$ long pipeline connecting four different Spanish river basins; the Tajo, Júcar, Segura and Guadiana, and until the present day with the desalination of seawater, the latest resource available by this agency [2].

Figure 1. The distribution network of the Mancomunidad de los Canales de Taibilla.

Spain's Programa AGUA was proposed in 2004 as a replacement for the Spanish National Hydrological Plan and represented a fundamental policy shift in national water management from large inter-basin water transfers to a commitment to desalination. The difficulties to increase (or even maintain) water transfers from the Tajo river, the abolition of the Ebro river transfer in 2004, the reduction of the expected flows from the Júcar river and on the other hand, the development of the desalination industry, are factors determining seawater desalination as an essential resource to maintain the water supply and ensure the quality of drinking water, especially in periods of shortage and in exceptional situations of water resource management.

The desalination of seawater is predominantly used to alleviate the problem of water scarcity in dry coastal regions [3] and accounts for a worldwide production capacity of more than $80 \mathrm{Mm}^{3} /$ day [4]. The main impact of desalination on the environment is related to the discharge of the brine produced into the sea, however monitoring programs designed and performed with maximum rigour and scientific quality allow to determine if brine discharge is affecting marine benthic communities [5-8]. Moreover, when significant impact on the environment has been observed, mitigation measures that increase the dispersal of brine have been successfully introduced $[3,9,10]$. Monitoring of brine discharge is regulated by national legislation and promoted by the MCT [11-14].

Since 2003, the Mancomunidad de los Canales del Taibilla has 4 seawater reverse osmosis desalination plants (Table 1), with a total capacity of $96 \mathrm{Mm}^{3}$ per year, in addition to the resources provided by the Taibilla river, the input of the Tajo-Segura transfer and the contributions of extraordinary resources, i.e. resources that are only used when no others are available such as some groundwater emergency wells or some inputs from the basins of the Segura and Júcar rivers, together with other resources such as contracts for the transfer of water rights signed with irrigation communities and agreements with the Acuamed society to exploit other desalination plants.

The annual freshwater demands and the analysis of the desalinated water contribution to the distribution system of the Mancomunidad de los Canales del Taibilla (MCT) are presented in this paper, with data provided by MCT. The historical evolution of the desalinated water over a decade, since the start of the desalination plant of Alicante I (September 2003), will allow the assessment of the contribution of desalination plants to resources managed by the MCT, which should ensure supply in this semi-arid zone of SE Spain, with a summer population of over 3 million inhabitants. 
Table 1. Desalination plants, property of the Mancomunidad de los Canales del Taibilla.

\begin{tabular}{lcl}
\hline Desalination plant & Annual production $\left(\mathrm{Mm}^{3} / \mathrm{y}\right)$ & Start-up \\
\hline Alicante I & 18 & September 2003 \\
Extension of Alicante I & 6 & February 2006 \\
Alicante II & 24 & July 2008 \\
San Pedro del Pinatar I & 24 & May 2005-January 2006* \\
San Pedro del Pinatar II & 24 & November 2006 \\
\hline
\end{tabular}

* In May 2005 the plant started up with a provisional discharge at the shoreline by dilution with a limited production (one third of total capacity on average). In January 2006, the outfall was completed and became fully operational with the discharge through the outfall.

\section{Material and Methods}

Daily production data was obtained from each desalination plant. Data was aggregated to obtain monthly and annual production for each plant. Performance of each plant was obtained dividing annual production by their maximum theoretical annual production, 24 $\mathrm{Mm}^{3} / \mathrm{y}$, except for Alicante II in 2008 that only $12 \mathrm{Mm} 3$ was used as theoretical maximum since this plant has started his production in July of this year (table 1).

Information on other freshwater sources used was obtained from the Mancomunidad de los Canales del Taibilla (MCT) annual reports. MCT also provide us with additional information on cost of each of the water sources they used.

\section{Results and discussion}

The annual freshwater demands for domestic use, including municipal resources, in the last 25 years, are presented in Figure 2. These demands have undergone oscillating changes, with a tendency to increase on average. During the period 1998-2005, the demand evolved with values consistent with the provisions of the Hydrological Plan of the Segura River Basin, approved by the Spanish Royal decree 1664/1998 of 24 July in the Official State bulletin [15], where the corresponding demands were evaluated for the 1st period (10 years) and for the 2 nd period (20 years). From 2006, this increasing trend in annual demand was interrupted and a decrease in demand began reaching a value of 201 $\mathrm{Mm}^{3}$ in 2013.

Figure 2. The annual freshwater demands and the municipal sources of the Mancomunidad de los Canales del Taibilla (MCT).

In the last decade, the increasing trend in demand (Figure 3), can be observed until 2005, with $227 \mathrm{Mm}^{3}$ (corresponding to the total resources of the MCT, $238 \mathrm{Mm}^{3}$, less municipal resources, $11 \mathrm{Mm}^{3}$ ). The introduction of desalinated water in the distribution system of the Mancomunidad de los Canales del Taibilla began in 2003 and in the period 2004 to 2013 , there has been a total production of $427 \mathrm{Mm}^{3}$ of potable water from desalination. The desalinated water production increased from 2004 to 2009 , as can be observed in Figure 3, with a maximum production of $72.6 \mathrm{Mm}^{3}$ in 2009. Afterwards, the annual production of desalinated water declined until 2013 when it dropped to $6.3 \mathrm{Mm}^{3}$ However, in 2012 this trend was interrupted as a result of increased production in the desalination 
plants to cope with the lack of resources available from the Tajo-Segura, after the collapse of part of the transfer infrastructure near the Ulea tunnel [16,17].

Figure 3. Annual demands (except municipal sources) and production of desalinated water in the Mancomunidad de los Canales del Taibilla (MCT).

These two very distinct phases in the evolution of the contribution of desalinated water are marked by the conditions of water resources available at all times.

In the years 2003-2009, the contributions of the "traditional" resources of the MCT decreased:

- The Taibilla river decreased its contribution, reaching a historical minimum in 2008, with a volume of $36.8 \mathrm{Mm}^{3}$.

- Resources from the Tajo-Segura also underwent a reduction during this period. Usually, periods of shortage of input at the head of the Segura basin coincide with a lower contribution from the Tajo-Segura.

The introduction of desalination from 2003 onwards allowed the amount of extra resources requested to be reduced, as was the case of transfer contracts of water rights to irrigation communities, among other resources.

In the period 2009-2013, conditions changed with more availability of traditional resources and the volume of desalinated water supplied to the network was reduced:

- Demand in the region underwent a progressive reduction, mainly as a consequence of the increased network performance (reduced losses) and water saving campaigns among the general public.

- The Taibilla river changed the trend of the previous period and the water volumes begin to rise, reaching a record of the last 20 years with $72.1 \mathrm{Mm}^{3}$.

- The increase in contributions at the headwaters of the Tajo river due to more humid years which motivated the increase of the resources from the Tajo-Segura transfer, reaching $99.5 \mathrm{Mm}^{3}$ in 2013.

This motivated the decrease in the production required from desalination plants during this period (2009-2013), except for the year 2012, when it was necessary to increase the water desalination production to cope with the water demand, after the collapse of the Ulea tunnel.

In recent years, the contribution of the river Taibilla and mainly the volume contributed by the Tajo-Segura transfer remain the major resources available to the MCT. However, the use of desalinated water as an available resource has been extremely important when the hydrological situation of the other resources have required the use of this endless source of water. As can be seen in Figure 4, the production of desalinated water amounted to $20.2 \%$ of the total production of the MCT network, during the period 2004-2013, similar to the contributions from the Taibilla river, the main and traditional resource of the MCT when it was created.

Figure 4. Water sources of the Mancomunidad de los Canales del Taibilla (2004-2013). 
The analysis of the annual production of the different resources experienced variations, as shown in Figure 5. Significant differences in the contribution of each source may be observed: while the desalination average in the decade was $20.2 \%$ the total production, in 2008 and 2009, it reached around 33\%, widely exceeding the Taibilla river contribution during this time and almost matching that of the Tajo-Segura transfers in 2008, with 34.6 $\%$

Figure 5. Distribution of resources from different sources in the network of the Mancomunidad de los Canales del Taibilla

The decline in demand due to the improvement of the network performance that has been observed in recent years together with the improvement in the availability of traditional resources of the MCT (Taibilla river and Tajo-Segura transfer) was the reason for the decrease in the supply of desalinated water in the last year studied. However, from 2004 the population supplied by the Mancomunidad de los Canales del Taibilla did not undergo any restrictions in spite of drought periods or problems with other sources (such as the breakdown of the Ulea tunnel).

These changes in the availability of different freshwater sources influenced the performance of the desalination plants (Table 2). Before 2009 the scarcity of surface water due to the drought period was managed with the introduction of desalinated water with a very high performance of the plants that reach an annual production close to $90 \%$ of the theoretical annual maximum for three of the four plants. Only Alicante II that was introduced in the system by the end of this period has a lower performance. After 2009 the decreasing trend in the performance of the plants is due to the lower needs of desalted water in the system only interrupted in 2012 due to the collapse of the Ulea tunnel. This is due to the lower cost of surface waters, when available, than that of desalted water, on average 0.5 euro $/ \mathrm{m}^{3}$, more or less the double than the cost of treated wastewater reuse. However, it has to be considered that desalination increase the reliability of the system since it is an endless source that it is not affected by climatic cycles.

Table 2: Annual performance of the MCT's Desalination Plants as percentage of their maximum annual production

\begin{tabular}{lrrrrr}
\hline Year & Alicante I & Alicante II & San Pedro I & San Pedro II & Average \\
\hline 2007 & 87.6 & & 91.8 & 85.1 & 88.2 \\
2008 & 82.9 & 34.3 & 91.4 & 89.2 & 74.5 \\
2009 & 75.0 & 44.6 & 79.6 & 68.3 & 66.9 \\
2010 & 81.0 & 8.2 & 84.9 & 40.1 & 53.6 \\
2011 & 65.0 & 1.9 & 76.1 & 1.0 & 36,0 \\
2012 & 60.7 & 24.1 & 71.1 & 27.1 & 45.7 \\
2013 & 14.6 & 4.1 & 5.0 & 3.6 & 6.8 \\
Average & 66.7 & 19.5 & 71.4 & 44.9 & 49.9 \\
\hline
\end{tabular}


In the future, desalination will play a more important role due to the implementation of the new rules of exploitation of the Tajo-Segura transfer. These new rules determine a maximum annual contribution of $90 \mathrm{Mm}^{3}\left(7.5 \mathrm{Mm}^{3} /\right.$ month), less than the previous maximum of $110 \mathrm{Mm}^{3}$. From 2004 to 2013, the water volume from the Tajo-Segura transfer widely exceeded $90 \mathrm{Mm}^{3}$ (with an annual average of $102 \mathrm{Mm}^{3}$ ), except in 2008 and 2010 where the volume contribution was 76 and $87 \mathrm{Mm}^{3}$ respectively, as shown in Figure 6. Moreover, in the Mediterranean basin, several studies have revealed general trends towards reduced precipitation and increased inter-annual variability, which are consistent with scenarios of future climate changes. As a consequence, it is expected that the magnitude, frequency and spatial area of droughts over the region will increase in the future $[18,19]$.

Figure 6. Resources from the Tajo-Segura transfer in the period 2004-2013. The new law establishes that the maximum annual contribution will be $90 \mathrm{Mm}^{3}$ per year.

This modification in the maximum annual contribution could suggest the need to increase desalinated water production, to cope with this decrease in the maximum assigned volume to the Tajo-Segura transfer.

\section{Conclusions}

Surface water, when available, has a lower cost than desalted water. However, in SE Spain there is a scarcity of surface water to supply the population that may increase in the future. The evolution of desalinated water as a resource in the network distributionproduction of the Mancomunidad de los Canales del Taibilla (MCT) during the period 2004-2013 permits desalination treatment to be considered as an important resource. During this period, desalination amounted for $20.2 \%$ of the total resources of the MCT, similar to the resources provided by one of the traditional sources such as the Taibilla river.

In some years during this period, the hydrological situation that determines the volumes produced by traditional sources of resources or the lack of availability of access to these resources for exceptional situations was resolved by increasing the production of the desalination plants to cope with the demand for water. This occurred in 2008 and 2009 when a third of the resources came from desalination, or in 2012 with the collapse of the Ulea tunnel in post-transfer that cut off the supply of Tajo-Segura transfer for several months when this represents, on average, almost half of the resources used by MCT. These results demonstrate that desalination increase the reliability of the system since their contribution may increase easily to face problems in the availability of other freshwater sources.

The change in the rule of exploitation of the Tajo-Segura transfer determines a new distribution of transferable volumes to supply. The decrease in the maximum annual volume allocated to supply poses a new scenario for the Mancomunidad de los Canales del Taibilla, where desalination has to play a fundamental role.

Therefore, desalination should be considered as a strategic solution, complementary to other available resources assigned to resolve the structural deficit. Since desalination is independent of hydrological cycles that determine the recurrent droughts in the southeast of Spain, it guarantees the supply of water, in an additional way and with an increasingly competitive technology. 


\section{Acknowledgement}

The authors are most grateful to the Mancomunidad de Canales del Taibilla (Ministerio de Agricultura y Pesca, Alimentación y Medio Ambiente, Spanish government), which has provided the water resource data presented in this paper and to the Ministerio de Economía y Competitividad (Spanish government), for the financial aid with Project CTM2013-46669-R. The manuscript has been revised by Anthony Efford.

\section{References}

[1] C.S. Ibor, M.G. Mollá, L.A. Reus and J.C. Genovés, Reaching the Limits of Water Resources Mobilisation: Irrigation Development in the Segura River Basin, Spain, Water Alternatives 4 (2011) 259-278.

[2] Mancomunidad de los Canales del Taibilla (MCT), Ministerio de Agricultura, Alimentación y Medio Ambiente, Gobierno de España, El Organismo y su evolución histórica (2012), · http://www.mct.es.

[3] Y. Del-Pilar-Ruso, E. Martinez-Garcia, F. Gimenez-Casalduero, A. Loya-Fernandez, L.M. Ferrero-Vicente, C. Marco-Mendez, J.A. de-la-Ossa-Carretero, J.L. Sánchez-Lizaso, Benthic community recovery from brine impact after the implementation of mitigation measures, Water Res., 70 (2015) 325-336.

[4] International Desalination Association (IDA), Desalination by the Numbers (2013). http://idadesal.org/desalination-101/desalination-by-the-numbers/.

[5] Y. Fernández Torquemada and J.L. Sanchez Lizaso, Monitoring brine discharges from seawater desalination plants in the Mediterranean, Int. J. Environ. Health. 1 (2007) 449 461.

[6] Y. Fernández Torquemada and J.L. Sánchez Lizaso, Responses of two Mediterranean seagrasses to experimental changes in salinity, Hydrobiologia. 669 (2011) 21-33.

[7] J.L. Sánchez-Lizaso, J. Romero, J. Ruiz, E. Gacia, J.L. Buceta, O. Invers, Y. Fernández Torquemada, J. Mas, A. Ruiz-Mateo and M. Manzanera. Salinity tolerance of the Mediterranean seagrass Posidonia oceanica: recommendations to minimize the impact of brine discharges from desalination plants, Desalination 221 (2008) 602-607.

[8] L. Marín-Guirao, J.M. Sandoval-Gil, J. Bernardeau-Esteller, J.M. Ruíz and J. L. SánchezLizaso, Responses of the Mediterranean seagrass Posidonia oceanica to hypersaline stress duration and recovery, Marine Environ. Research. 84 (2013) 60-75.

[9] A. Loya-Fernández, L.M. Ferrero-Vicente, C. Marco-Méndez, E. Martínez-García, J. Zubcoff and J.L. Sánchez-Lizaso, Comparing four mixing zone models with brine discharge measurements from a reverse osmosis desalination plant in Spain, Desalination. 286 (2012) 217-224.

[10] Y. Fernández-Torquemada, J.M. González-Correa and J.L Sánchez-Lizaso, Echinoderms as indicators of brine discharge impacts, Desalination and Water Treatment. 51 (2013) 567-573.

[11] Y. Fernández Torquemada, J.M. González Correa, A. Carratalá and J.L. Sanchez Lizaso, Preliminary results of the monitoring of the brine discharge produced by the SWRO desalination plant of Alicante (SE Spain), Desalination. 182 (2005) 395-402.

[12] Y. Fernández Torquemada, A. Loya, Y. Múgica, J.L. Sánchez Lizaso, J. Templado, M. Calvo, A. Antoranz and J.M. Cortés, Monitoring the brine discharge from a desalination 
plant in the Mediterranean. IDA World Congress, Maspalomas, Gran Canaria, Spain, (2007) MP07-233.

[13] Y. Fernández-Torquemada, J.M. Gónzalez-Correa, A. Loya, L.M. Ferrero, M. DíazValdés, J.L. Sánchez-Lizaso, Dispersion of brine discharge from seawater reverse osmosis desalination plants, Desalination and Water Treatment. 5 (2009) 137-145.

[14] Y. Del-Pilar-Ruso, J.A. De-la-Ossa-Carretero, A. Loya-Fernández, L.M. Ferrero-Vicente, F. Giménez-Casalduero and J.L. Sánchez-Lizaso, Assessment of soft-bottom Polychaeta assemblage affected by a spatial confluence of impacts: Sewage and brine discharges, Marine Pollution Bulletin. 58 (2009) 765-786.

[15] Boletín Oficial del Estado (BOE). Real Decreto 1664/1998, de 24 de julio, por el que se aprueban los Planes Hidrológicos de cuenca, (1998). http://www.boe.es/buscar/doc.php?id=BOE-A-1998-19358.

[16] Sindicato Central de Regantes del Acueducto Tajo-Segura (SCRATS). Memoria 2012, Technical document (2012). http://www.scrats.es/ftp/memorias/Memoria-regantes12.pdf

[17] Confederación Hidrográfica del Segura (CHS). Ministerio de Agricultura, Alimentación y Medio Ambiente. Gobierno de España. El agua vuelve a circular por el túnel de Ulea. (2013).http://www.chsegura.es/export/descargas/informaciongeneral/comunicacion/no ticias/docsdescarga/2013-03-Marzo/20130327-NOTA-Apertura-Pruebas-Tnel-Ulea.pdf

[18] Pal J.S., Giorgi F. \& Bi X. (2004) Consistency of recent European summer precipitation trends and extremes with future regional climate projections. Geophysical Research Letters, 31, L13202 doi:10.1029/2004GL019836.

[19] Magalhaes, M. F.; P. Beja, I. J . Schlosser \& M. J. Collares-Pereira 2007. Effects of multiyear droughts on fish assemblages of seasonally drying Mediterranean streams. Freshwater Biology (2007) 52, 1494-1510. 


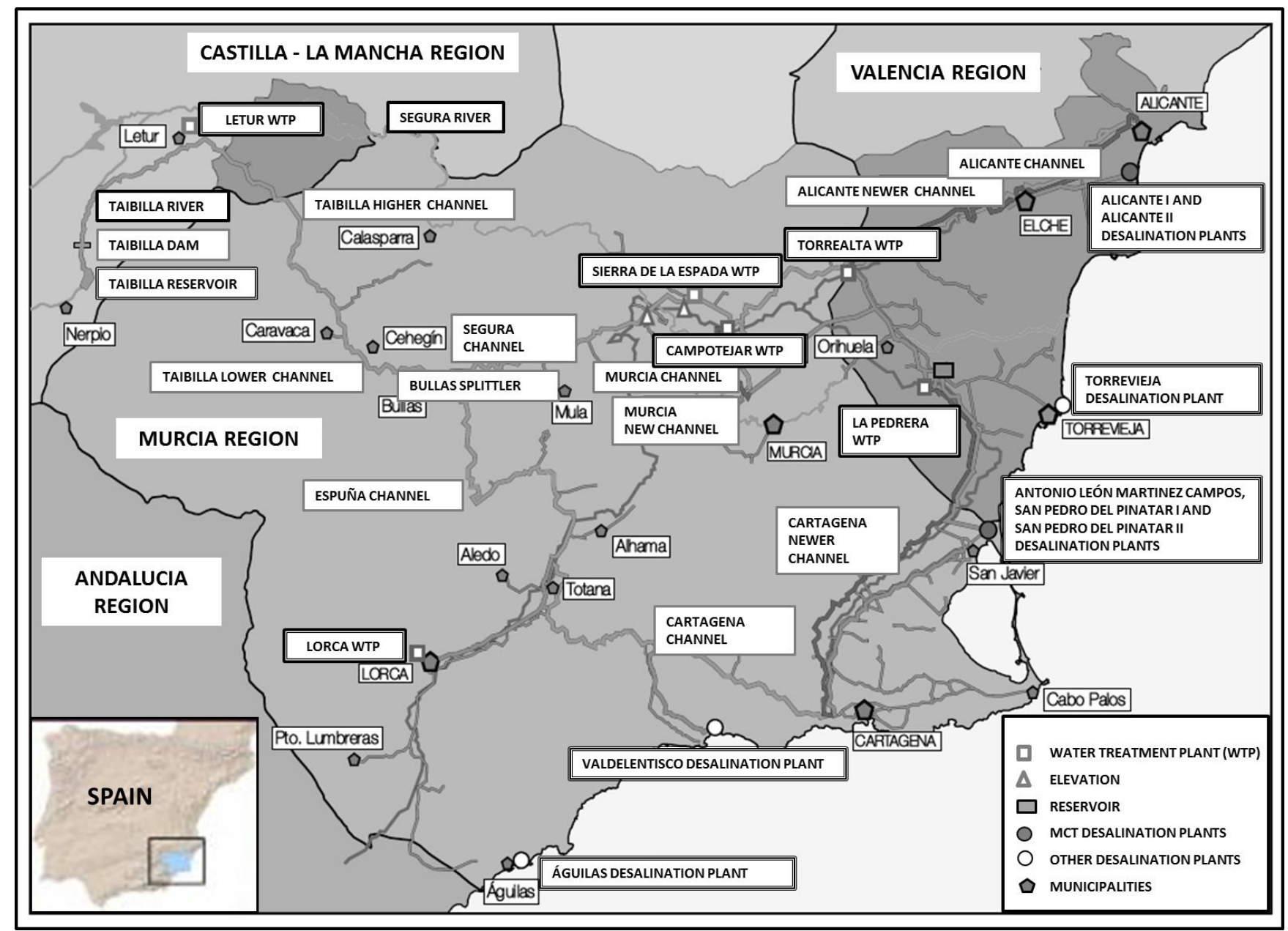

Figure 1. The distribution network of the Mancomunidad de los Canales de Taibilla. 


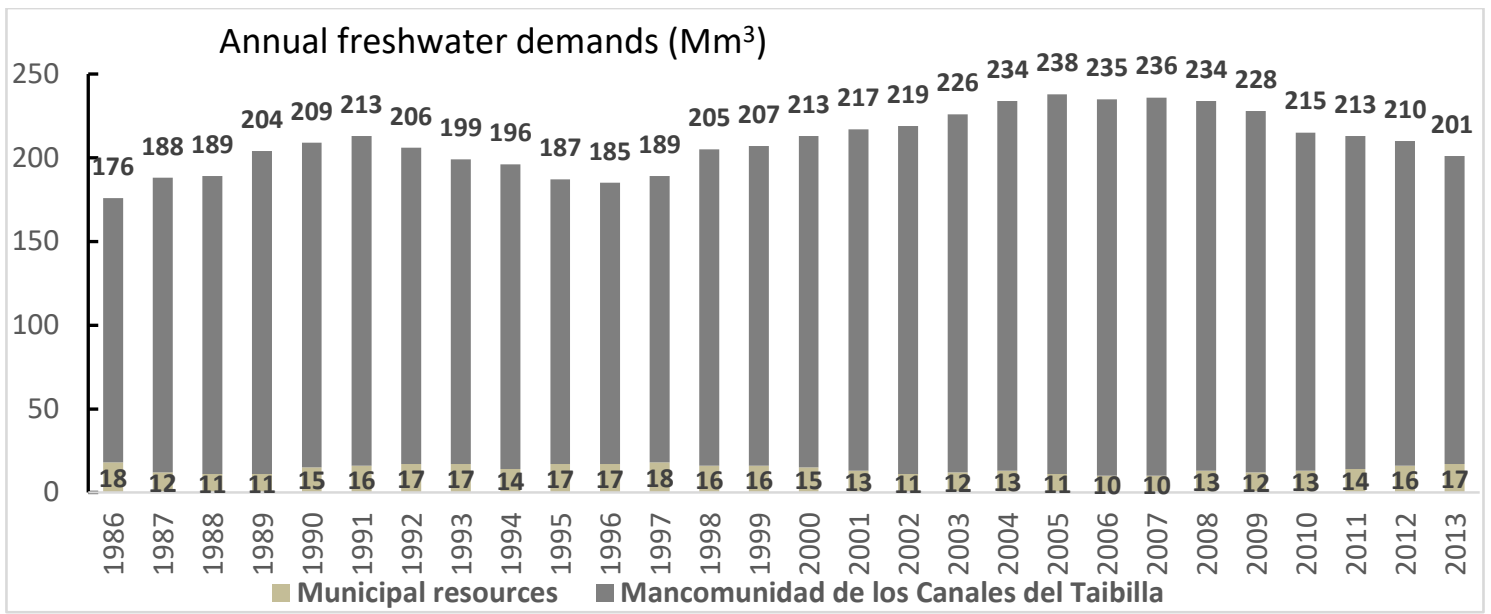

Figure 2. The annual freshwater demands and the municipal sources of the Mancomunidad de los Canales del Taibilla (MCT). 


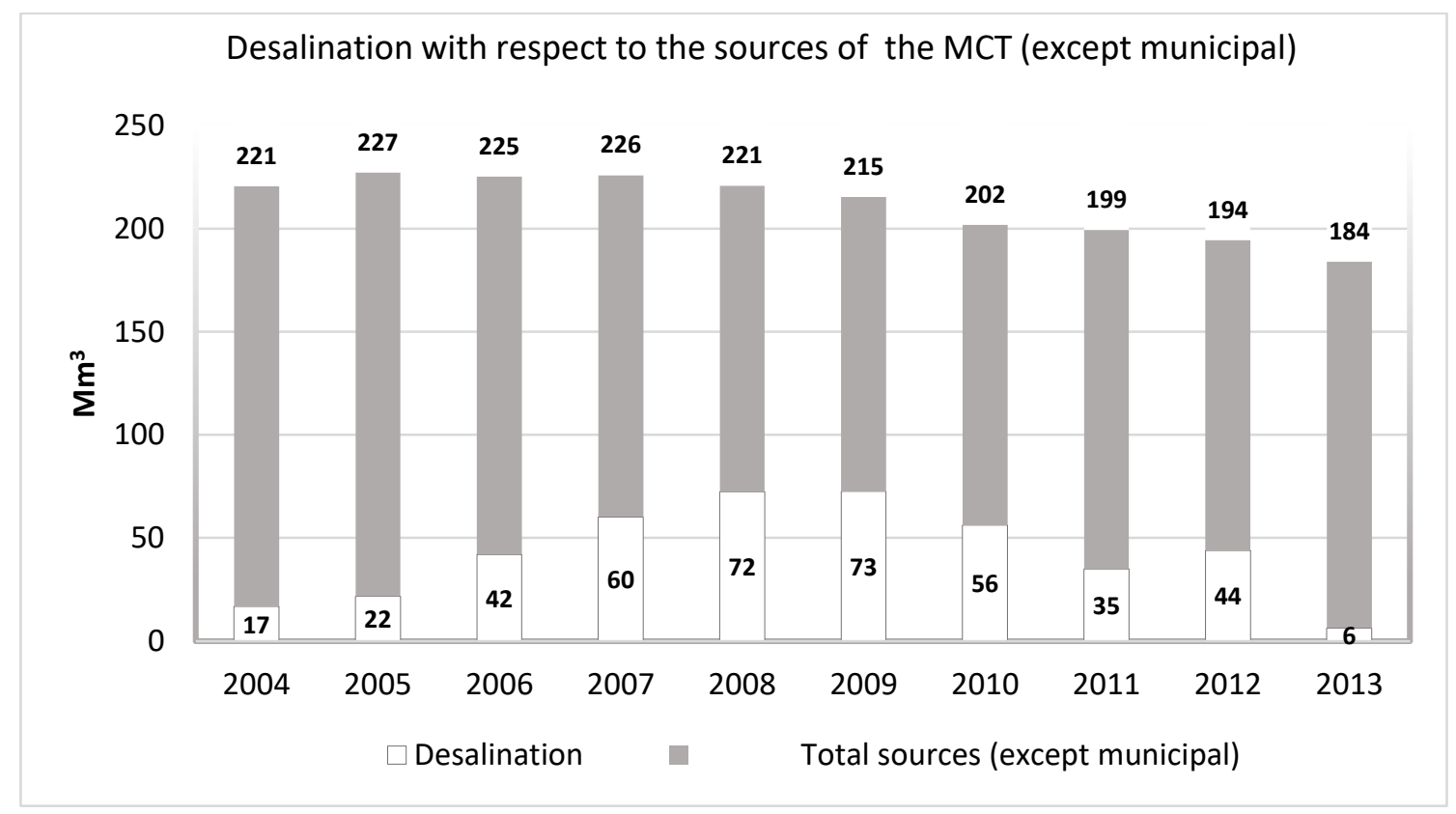

Figure 3. Annual demands (except municipal sources) and production of desalinated water in the Mancomunidad de los Canales del Taibilla (MCT). 
Water sources of the MCT (2004-2013)

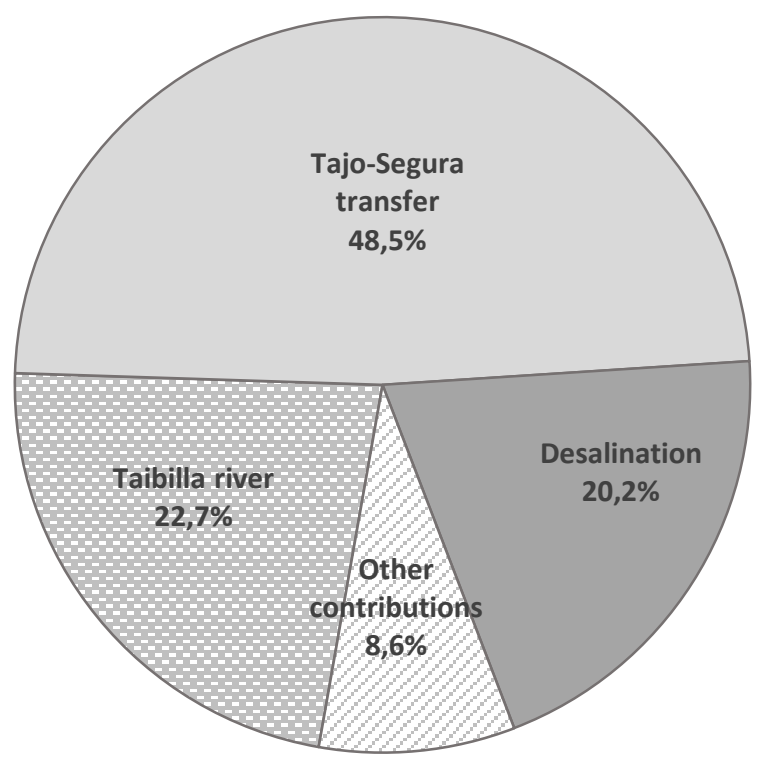

Figure 4. Water sources of the Mancomunidad de los Canales del Taibilla (2004-2013). 


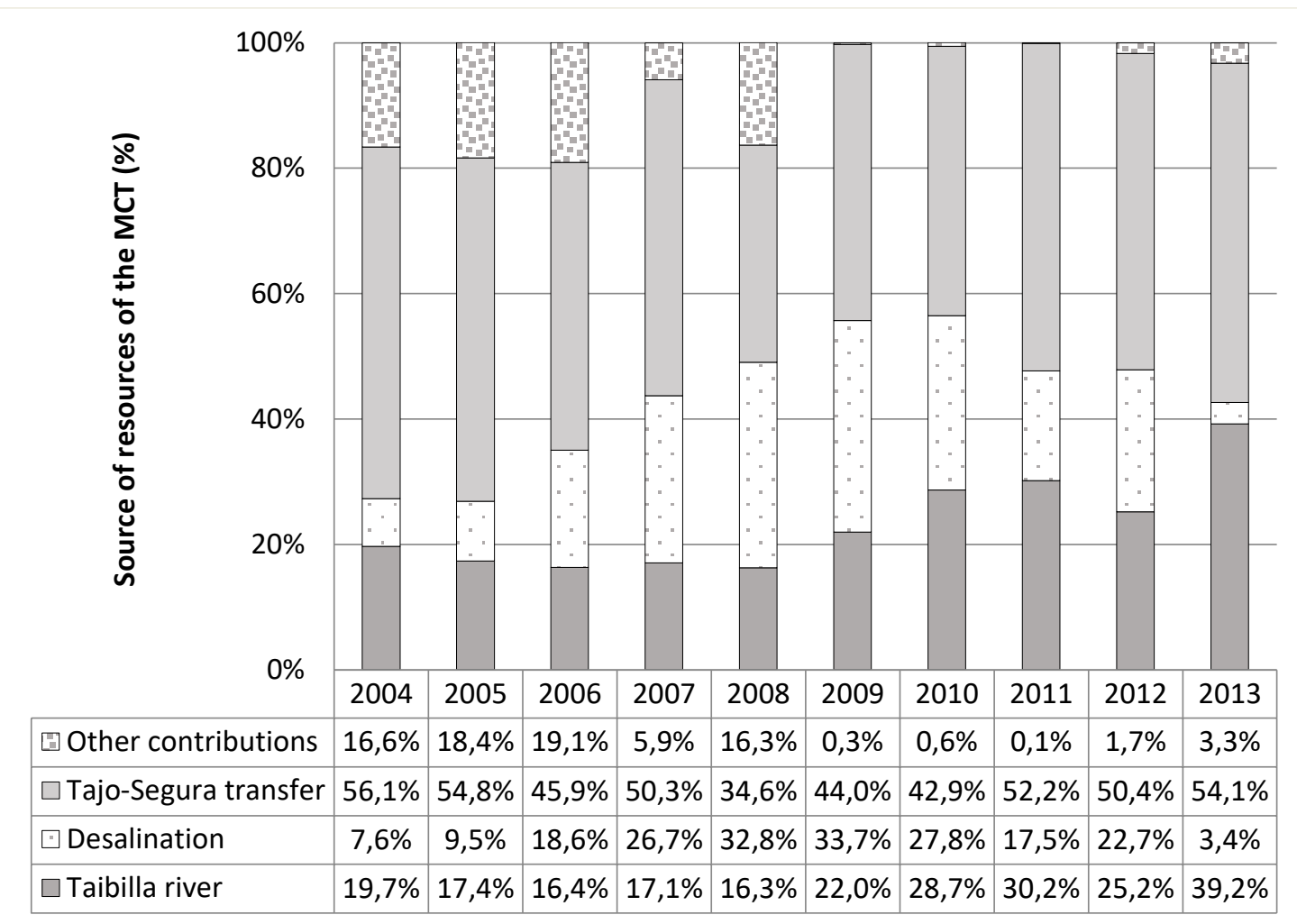

Figure 5. Distribution of resources from different sources in the network of the Mancomunidad de los Canales del Taibilla (MCT). 


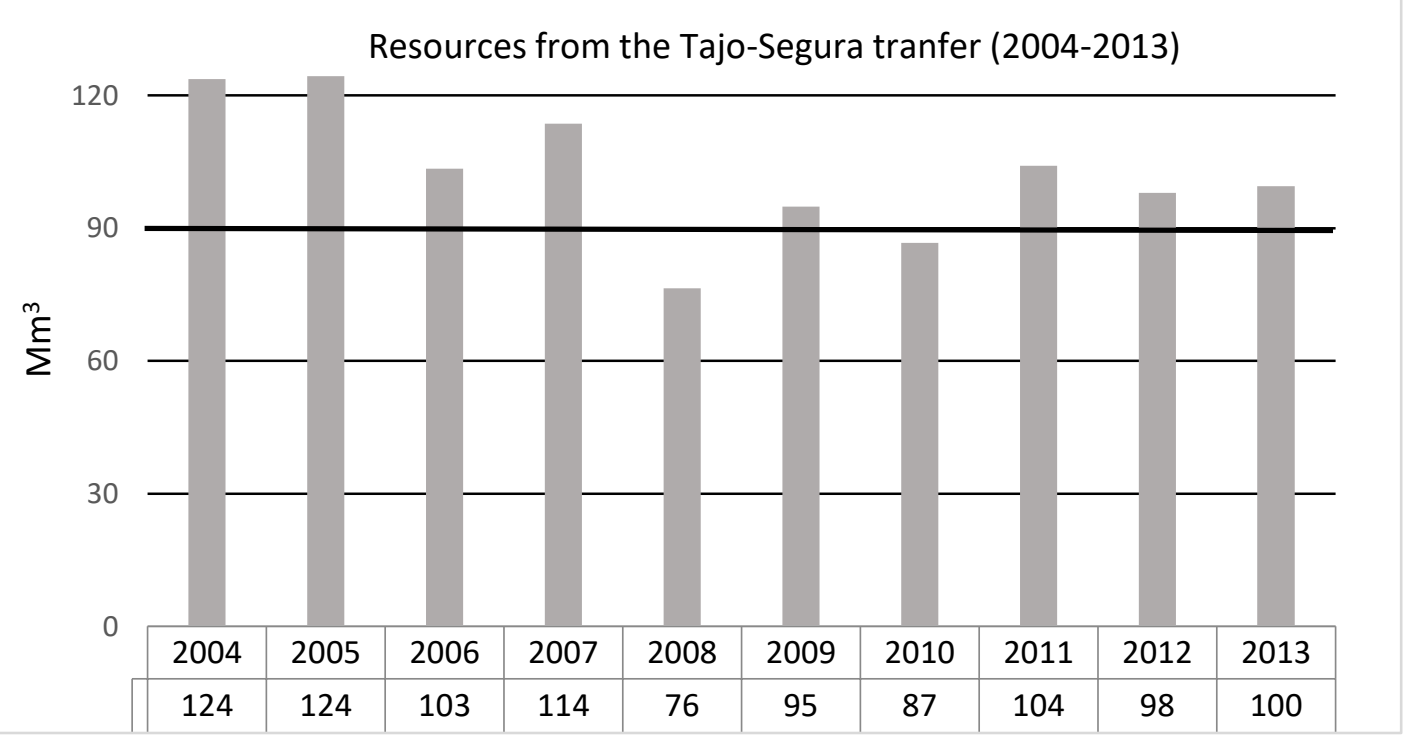

Figure 6. Resources from the Tajo-Segura transfer in the period 2004-2013. The new law establishes that the maximum annual contribution will be $90 \mathrm{Mm}^{3}$ per year. 